\title{
Analisis Penerapan Metode Games Education dalam Meningkatkan Motivasi Belajar Siswa Sekolah Dasar
}

\author{
Ayudia Pratiwi, Fadlilatul Hikmah, Adi Apriadi Adiansha ${ }^{*}$, Suciyati \\ STKIP Taman Siswa Bima, Bima, Indonesia \\ *Coresponding Author: adiapriadiadiansyah@gmail.com \\ Dikirim: 07-06-2021 ; Direvisi: 08-06-2021 ; Diterima: 08-06-2021
}

\begin{abstract}
Abstrak: Penelitian ini dilatar belakangi oleh beberapa permasalahan yang ada pada proses belajar mengajar di sekolah dasar seperti kurangnya motivasi belajar siswa sehingga berdampak pada prestasi. Kurangnya penerepan media pembelajaran yang menarik perhatian siswa agar memiliki motivasi belajar yang baik, sehingga materi yang diajarkan menjadi tidak berjalan sesuai dengan harapan guru dan juga sekolah. Permasalahan tersebut memperlihatkan kurangnya motivasi belajar siswa dalam belajar. Tujuan dari penelitian ini adalah untuk melihat bagaimana pengaruh pembelajaran berbasis games education dalam meningkatkan motivasi belajar siswa sekolah dasar. Sedangkan jenis penelitian ini adalah (deskriptif kualitatif). Deskriptif kualitatif merupakan penelitian yang memusatkan pada masalah-masalah sebagaimana adanya saat penelitian dilaksanakan. Jenis penelitian ini adalah kualitatif dengan metode deskriptif. Keabsahan data dilakukan dengan triangulasi sumber, triangulasi metode dan triangulasi teori. Analisis data digunakan model analisis interaktif yang dilaksankan melalui tiga komponen, yaitu: reduksi data, sajian data dan penarikan kesimpulan. Hasil penulisan ini menunjukan bahwa adanya pengaruh pembelajaran berbasis games education dalam meningkatkan motivasi belajar siswa Sekolah Dasar. Hal ini dapat dilihat dari hasil belajar siswa yang menggunakan media pembelajaran berbasis games dengan pembelajaran yang menggunakan media pembelajaran lain. Dimana dengan menggunakan pembelajaran berbasis games education motivasi belajar siswa meningkat dan pembelajaran lebih efisien dan efisien.
\end{abstract}

Kata Kunci: Games Education; Motivasi Belajar

\begin{abstract}
This research is motivated by several problems that exist in the teaching and learning process in elementary schools such as the lack of student learning motivation so that it has an impact on achievement. The lack of application of learning media attracts students' attention so that they have good learning motivation so that the material being taught does not run according to the expectations of teachers and schools. These problems show the lack of student motivation in learning. The purpose of this study was to see how the influence of games-based learning education in increasing the learning motivation of elementary school students. While the type of this research is (qualitative descriptive). Qualitative descriptive is research that focuses on problems as they were when the research was carried out. This type of research is qualitative with a descriptive method. The validity of the data is done by triangulation of sources, triangulation of methods, and triangulation of theory. Data analysis used an interactive analysis model which was carried out through three components, namely: data reduction, data presentation, and conclusion drawing. The results of this paper indicate that there is an effect of games-based learning in increasing the learning motivation of elementary school students. This can be seen from the learning outcomes of students who use games-based learning media with learning that uses other learning media. Whereby using game-based learning, students' learning motivation increases, and learning is more efficient and efficient.
\end{abstract}

Keywords: Games Education; Motivation to Learn. 


\section{PENDAHULUAN}

Belajar merupakan suatu proses kegiatan memperoleh informasi dari berbagai sumber, atau kegiatan yang dilakukan dalam mempelajari suatu hal agar mencapai tujuan yang diinginkan dari pengalaman yang diperoleh, sehingga terjadi perubahan perilaku. Kegiatan belajar bisa dilakukan dimana pun, asalkan pembelajaran tersebut merasa nyaman dan mendukung dalam kegiatan belajar. Namun, kegiatan belajar secara formal dilaksanakan disekolah, dimana sekolah tempat pertemuan guru dan peserta didik dalam kegiatan pembelajaran (Rifki,2015).

Motivasi belajar adalah proses yang meberikan kekuatan, mengarahkan dan mempertahankan perilaku belajar siswa. Motivasi yang terdapat pada siswa ada dua macam, yaitu motivasi instrik dan ekstrinsik. Motivasi instrik terkait dengan melakukan sesuatu untuk mendapatkan sesuatu yang lain (Santrock, 2014). Guru sebagai fasilitator hendaknya memiliki kemampuan lebih, tidak hanya dengan kemampuan mengajar tetapi diharuskan pula dapat mengembangkan media untuk proses pembelajaran (Aprilia dkk, 2019). Ahyar (2012), media pembelajaran merupakan bagian tak terpisahkan dari proses pembelajaran, pemanfaatan media pembelajaran merupakan upaya kreatif dan sistematis untuk menciptakan pengalaman yang dapat pembelajaran peserta didik, sehingga pada akhirnya dihasilkan lulusan yang berkualitas. Karena pada fakta yang terlihat siswa sekolah dasar lebih senang ketika pembelajaran mereka dikaitkan dengan permainan atau dikenal dengan istilah belajar sambil bermain.

Purwanto (2010), faktor-faktor yang mempengaruhi prestasi belajar adalah (a) faktor dari dalam diri individu, yanng terdiri dari faktor fisiologi adalah kondisi jasmani, dan kondisi panca indra, sedangkan faktor psikolis yaitu bakat, minat, kecerdasan, motivasi berprestasi dan kemampua kognitif, (b) faktor dari luar individu, yang terdiri dari faktor lingkungan dan faktor instrumental. Faktor lingkungan yaitu lingkungan sosial dan lingkungan alam. Sedangkan faktor instrumental yaitu kurikulum, bahan guru, sarana, administrasi dan manejemen.

Dari permasalahan diatas maka penulis tertarik untuk mengkaji tentang “ analisis motivasi belajar siswa sekolah dasar (SD) melalui pembelajaran berbasis games education" Penggunaan media pembelajaran dalam bentuk permainan (games), akan sangat menyenangkan dan akan lebih bermakna bagi siswa. Hal ini diperkuat dengan pendapat piaget (dalam beetletsoon, 2013) yang menyatakan bahwa pembelajaran bermakna dan berorientasi pada kebutuhan dan perkembangan anak.

Salah satu masalah dalam pembelajaran di SD adalah rendahnya motivasi belajar. Motivasi merupakan daya penggerak yang mendorong seseorang melakukan suatu pekerjaan untuk dapat mencapai tujuan yang telah ditentukan (Sadirman, 2011: 73). Dalam proses pembelajaran, motivasi berperan sangat penting Fungsi motivasi dalam belajar adalah mendorong seseorang untuk berbuat dan bertindak; motivasi menentukan arah perbuatan; motivasi menyeleksi perbuatan kita (Faturrohan, dkk. 2007: 20). Lebih lanjut Sadirman menjelaskan apabila siswa termotovasi dalam belajar maka akan dilihat beberapa indikator sebagai berikut: tekun menghadapi tugas; ulet menghadapi kesulitan; menunjukan minat terhadap macam-macam masalah orang dewasa; lebih senang bekerja mandiri; cepat bosan pada tugas-tugas rutin, dan; dapat mempertahankan pendapatnya (Sadirman, 2011: 83). 
Salah satu metode untuk meningkatkan motivasi belajar adalah education games. Education games (permainan edukatif) menurut Andang Ismail dalam bukunya education games, yaitu suatu kegiatan yang sangat menyenangkan dan dapat merupakan cara atau alat pendidikan yang bersifat mendidik (Ismail, 2006: 119). Lebih lanjut dijelaskan bahwa fungsi permainan edukatif adalah sebagai berikut: (a) Memberikan ilmu pengetahuan kepada anak melalui proses pembelajaran bermain sambil belajar; (b) Merangsang perkembangan daya pikir, dan daya cipta dan bahasa agar dapat menumbuhkan sikap, mental, serta akhlak yang baik; (c) Menciptakan lingkungan bermain yang menarik, memberikan rasa aman dan menyenangkan; (d) Meningkatkan kualitas pembelajaran anak (Ismail, 2006: 150).

Permainan dalam education games tentu saja memiliki beberapa persyaratan. Syarat-Syarat Education Games (Permainan Edukatif) adalah: (a) Mudah dibongkar pasang. Alat permainan yang mudah dibongkar pasang, dapat diperbaiki sendiri lebih ideal daripada mobil-mobilan yang dapat bergerak sendiri; (b) Mengembangkan daya fantasi. Alat permainan yang sifatnya mudah dibentuk dan diubah-ubah sangat sesuai untuk mengembangkan daya fantasi, yang memberikan kepada anak kesempatan untuk mencoba dan melatih daya-daya fantasinya. Sesuai dengan ajaran pendidikan moderen alat-alat yang dapat menunjang perkembangan fantasi misalnya dengan kapur berwarna, papan tulis, kertas origami; (c) Tidak berbahaya. Para ahli telah meneliti alat-alat permainan sependapat tentang alat permainan yang suka mendatangkan bahaya bagi anak-anak yaitu tangga, gunting yang runcing ujungnya, pisau tajam, kompor dan sebagainya (Zulkifly, 2003: 43).

Dari uraian di atas maka artikel ini akan membasah tentang “ Analisis Motivasi Belajar Siswa Sekolah Dasar Melalui Pembelajaran Berbasis Games Education”..

\section{METODE PENELITIAN}

Metode yang digunkan dalam penulisan ini adalah metode studi pustka yang dimana metode penelitian ini adalah teknik pengumpulan data mengadakan studi menelaah terhadap buku-buku, litertur-litertur, catatan-catatan dan laporan-laporan yang ada hubunganya dengan masalah yang dipecahkan (Muhammad, 2014). Pendapat lain juga dikemukakan oleh (Sugiyono, 2012) bahwa studi pustaka adalah kajian teoritis, referensinya serta literatur ilmiah lainya yang berkaitang dengan budaya nilai dan norma yang dikembangkan pada situasi sosial yang diteliti.

Jadi bisa disimpulkan, metode studi pustaka adalah metode penelitian yang digunakan untuk penelitian pada kondisi obyek yang alamiah, yang dimana peneliti sebagai instrumen kunci, teknik pengumpulan data dilakukan secara gabungan, analisis data bersifat induktif (mengandung pembuktian dan contoh-contoh fakta), dan hasil penelitian kualitatif lebih menekankan makna dari pada generalisasi.

\section{HASIL DAN PEMBAHASAN}

Hasil dan pembahasan penulisan artikel ini merupakan data yang dikumpulkan dari pengamatan terhadap beberapa artikel tentang pembelajaran berbasis games education terhadap motivasi siswa sekolah dasar. Penelitian ini ingin melihat seberapa jauh pengaruh pembelajaran yang menggunakan permainan (games) terhadap motivasi belajar siswa sekolah dasar. 
Motivasi belajar suatu unsur yang sangat penting dalam proses pembelajaran, karena tanpa sadar bahwa motivasi belajar dapat dan sangat berpengaruh dengan aktif dan pasifnya siswa dalam mengikuti proses pembelajaran di kelas. Kondisi ini sangat berpengaruh besar pada prestasi belajar siswa. Motivasi belajar adalah dorongan internal dan eksternal pada siswa yang sedang belajar untuk mengadakan perubahan tingkah laku pada umumnya dengan beberapa indikator atau unsusr yang mendukung (Hamzah, 2013; Yulianci et al., 2021).

Salah satu perangkat pembelajaran yang cocok diterapkan pada sekolah dasar untuk meningkatkan motivasi belajar siswa adalah pembelajaran berbasis games education. Menurut Marc Prensky (2012), games education adalah game yang didesain untuk belajar, tapi tetap bisa menawarkan bermain dan bersenang-senang. Games education adalah permainan yang dibuat dengan tujuan pembelajaran yang bukan hanya bermaksud menghibur sehingga diharapkan bisa menambah wawasa pengetahuan (Novia, 2016). Pengertian lain juga diuraikan oleh (Alya, 2016), game education adalah yang tujuan utamanya untuk mengajar, belajar dan juga menghibur.

Berdasarkan pengertian tentang games education di atas, bahwa games education termasuk salah satu media pembelajaran, dimana dalam media ini memiliki teknik dalam kegiatan belajar mengajar dengan tujuan supaya proses interaksi komunikasi edukasi berlangsung secara tepat atau dikatakan efektif dan efisien sehingga dapat me rangsang pikiran, perasan, perhatian dan minat peserta didik dalam kegiatan pembelajaran yang dilakukan.

Tabel 1. Artikel Yang Dianalisis

\begin{tabular}{|c|c|c|c|}
\hline No. & Judul Artikel & Penulis artikel & Tahun \\
\hline 1. & $\begin{array}{l}\text { Penerapan Model Pembelajaran Team Games } \\
\text { Tournamen (TGT) Untuk Meningkatkan } \\
\text { Motivasi Dan Keterampilan Berbicara Kelas IV } \\
\text { SDN } 2 \text { Tihingan }\end{array}$ & $\begin{array}{l}\text { Ni Md Ayu Widiantari, } \\
\text { Kt Pudjawan, Gst Ngurah } \\
\text { Japa }\end{array}$ & 2013 \\
\hline 2. & $\begin{array}{l}\text { Pengembangan Game Petualangan "Si Bolang" } \\
\text { Sebagai Media Pembelajaran Tematik Untuk } \\
\text { Meningkatkan Motivasi Dan Prestasi Belajar } \\
\text { Siswa Kelas V Sekolah Dasar }\end{array}$ & $\begin{array}{c}\text { Sunarti, Selly } \\
\text { Rahmawati, dan Setia } \\
\text { Wadani }\end{array}$ & 2016 \\
\hline 3. & $\begin{array}{l}\text { Pengembangan Media Pembelajaran Permainan } \\
\text { Ular Tangga Untuk Meningkatkan Motivasi } \\
\text { Belajar Dan Hasil Belajar IPS Di Sekolah Dasar }\end{array}$ & Rifki Afandi & 2015 \\
\hline 4. & $\begin{array}{l}\text { Meningkatkan Motivasi Belajar Siswa Dengan } \\
\text { Menggunakan Metode Bermain Sambil Belajar } \\
\text { (Permainan Monopoli) Pada Pokok Bahasan } \\
\text { Penggolongan Hewan di Kelas IV SDN } 101765 \\
\text { Bandar Setia }\end{array}$ & Belladina Nasution & 2012 \\
\hline 5. & $\begin{array}{l}\text { Pengembangan Media Ludo Raksasa Tema } \\
\text { Selalu Berhemat Energi Untuk Menigkatkan } \\
\text { Motivasi Belajar Siswa Kelas IV Sekolah Dasar }\end{array}$ & $\begin{array}{l}\text { Aprilia Nur Fajar Jihan, } \\
\text { Fien Reffieane Dan } \\
\text { Prasena Arisyanto }\end{array}$ & 2019 \\
\hline
\end{tabular}

Ni Made Ayu Widiantari dkk (2013), yang berjudul “ Penerapan model pembelajaran teams games tournament (TGT) untuk meningkatkan motivasi dan keterampilan berbicara kelas IV SDN 2 tihingan". Dari tulisan ini menerangkan bahwa pada siklus I rata-rata motivasi belajar siswa sebesar 73 dengan presentase tingkat motivasi secara klasikal sebesar 73\% dalam kategori sedang. Sedangkan rata- 
rata keterampilan berbicara siswa mencapai 71 dengan presentase keterampilan berbicara secara klasilal sebesar $71 \%$ dalam kategori sedang. Dari 17 orang siswa, 3 diantaranya telah mencapai nilai diatas KKM. Pada siklus I ketuntasan belajar mencapai $17,46 \%$.

Pada siklus II rata-rata motivasi siswa mencapai 84 dengan presentase tingkat motivasi secara klasikal sebesar $84 \%$ dalam kategori tinggi. Pada siklus II motivasi belajar siswa telah mencapai kriteria keberhasilan yang ingin dicapai yaitu nilai motivasi siswa sama deengan atau lebih dari 80 dengan presentase tingkat motivasi belajar siswa sama dengan atau lebih dari $84 \%$. Dengan demikian pada siklus II keterampilan berbicara siswa dan presentase keterampilan berbicara secara klasikal telah mencapai kriteria keberhasilan yaitu nilai keterampilan berbicara sama dengan atau lebih dari KKM yaang ditetapkan oleh peneliti yaitu 80 dan presentase keterampilan berbicara secara klasikal sama dengan 86,47\%. Penelitian ini dihentikan pada siklus II, karena pada siklus II motivasi belajar dan keterampilan berbicara siswwa telah mencapai kriteria keberhasilan yang ditetapkan dalam penelitian.

Dalam artikel lain yang ditulis oleh Sunarti dkk (2016), yang berjudul "Pengembangan Game Petualangan (Si Bolang) Sebagai Media Pembelajaran Tematik Untuk Meningkatkan motivasi dan prestasi belajar siswa kelas V sekolah dasar" dalam tulisannya mengatan bahwa terdapat data motivasi siswa yang diajar dengan menggunakan media gambar memiliki nilai signifikan $>0,05$ berarti data berdistribusi nirmal, sedangkan data motivasi belajar siswa yang diajarkan dengan menggunakan game petualangan si bolang $<0,05$, berati data berdistribusi tidak normal. Data nilai dengan menggunakan media gambar $<0,05$ berarti data berdistribusi tidak normal. Untuk data nilai dengan menggunakan media game petualangan si bolang $>0,05$ berarti data berdistribusi normal. Nilai signifikansi prestasi ini > dari 0,05 seingga Ho diterima yang beratti tidak ada perbedaaan prestasi belajar antara siswa yang diajarkan dengan menggunakan media gambar dan siswa yang diajar dengan menggunakan media game petualangan si bolang. Pada pengujian hipotesis kedua, nilai signifikansi motivasi adalah 0,000. Nilai tersebut < 0,05 sehingga Ho ditolak, berarti ada perbedaan motivasi belajar antara siswa yang diajarkan dengan media gambar dengan siswa yang diajarkan dengan menggunakan media petualangan si bolang. Berdasarkan analisis deskriptif dapat terlihat mean motivasi belajar siswa yang diajar dengan menggunakan media gambar adalah 24,64, sedangkan mean motivasi belajar siswa yang diajar dengan menggunakan media petualangan si bolang adalah 33,32. Jadi dapat disimpulkan bahwa media game petualangan si bolang lebih efektif untuk meningkatkan motivasi belajar siswa dibandingkan dengan menggunakan media gambar.

Rifki Afandi, (2015) dalam artikelnya juga membahas tentang games education yang berjudul "Pengembangan Media Pembelajaran Permainan Ular Tangga Untuk Meningkatkan Motivasi Belajar Siswa dan Hasil Belajar Ips Sekolah Dasar" dalam penelitian ini mengatakan bahwa penggunaan media pembelajaaran permainan ular tangga memberikan kriteria penilaian yang sangat baik. Berdasarkan data yang sudah diolah, motivasi siswa pada aspek keaktifan dan semangat belajar menunjukan bahwa sebelum diterapkan media pembelajaran permainan ular tangga pada aspek tersebut sebesar $28,4 \%$ siswa yang memiliki motivasi belajar dalam pembelajaran IPS sangat rendah. Sedangkan pada saat diterapkan media pembelajaran permainan 
ular tangga motivasi belajar siswa pada aspek keaktifan dan semangat belajar sebesar 95,1\% siswa yang memiliki motivasi belajar IPS, setelah diterapkan media pembelajaran permainan ular tangga motivasi belajar siswa mengalami peningkatan $66,7 \%$. Hal tersebut motivasi siswa pada aspek keaktifan dan semangat dalam pembelajaaran IPS sangat tinggi setelah menerapkan media pembelajaran permainan ular tangga.

Belladina nasution, (2012) dalam artikelnya yang berjudul "Peningkatan Motivasi Belajar Siswa Dengan Menggunakan Metode Bermain Sambil Belajar (Permainan Monopoli) Pada Pokok Bahasan Penggolongan Hewan Di Kelas IV SDN 101765 Bandar Setia". Sebelum melakukan penelitian, peneliti melakukan observasi di kelas IV SDN no. 101765 bandar setia terhadap 10 orang siswa sebagai sampel. Dari observasi tersebut diperoleh hasil bahwa $80 \%$ siswa tidak mempunyai motivasi belajar, 60\% siswa tidak paham dengan materi yang disampaikan, 30\% siswa tidak aktif dalam proses belajar mengajar, 50\% tidak mengerti pertanyaan yang diajukan. Dengan demikian permasalahan yang diteliti dalam penelitian ini adalah rendahnya motivasi belajar.

Setelah diterapkan metode bermain sambil belajar (permaian monopoli), hasil penelitian menunjukan bahwa kondisi awal, nilai rata-rata motivasi siswa adalah 51,5. Pada siklus I nilai rata-rata motivasi belajar siswa naik yaitu 61,48, sedangkan pada siklus II nilai rata-rata motivasi belajar siswa naik menjadi 79,4 secara klasikal jumlah siswa yang meningkat motivasi belajarnya pada kondisi awal adalah 2 orang siswa (8\%), pada siklus I naik menjadi 5 orang siswa (20\%), sedangkan pada siklus II meningkat menjadi 22 orang siswa (88\%). Dengan demikian dapat diambil kesimpulan bahwa penggunaan metode bermain sambil belajar (permainan monopoli) dapat meningkatkan motivasi belajar siswa pada pokok bahasan penggolongan hewan dikelas IV SDN No. 101765 Bandar Setia.

Penelitian lain yang ditulis oleh ANF Jihan dkk, (2019) yang berjudul “ Pengembangan Media Ludo Raksasa Berhemat Energi Untuk Meningkatkan Motivasi Belajar Siswa Kelas IV Sekolah Dasar " dalam penelitian ini melakukan uji coba tingkat kepratisan media dan hal ini dilakukan dengan melakukan uji coba produk ludo raksasa dengan pembagian lembar angket tanggapan siswa dan guru. Media ludo raksasa diuji cobakan dalam kelas IV SD Negeri Tlogosari Wetan 01, SD Negeri Tlogosari Kulon 01, dan SD Negeri Tlogosari Kulon 03. Hasil rata-rata presentase kepraktisan angket tanggapan siswa sebesar 99,07\% dan hasil rata-rata presentase kepraktisan angket tanggapan guru terhadap media ludo raksasa sebesar 96,52\% hal ini menyatakan bahwa media ludo raksasa dapat digunakan tanpa revisi.

Kevalidan media ludo raksasa diperoleh dari presentase hasil validasi media dan materi terhadap media ludo raksasa. Penelitian kevalidan media ludo raksasa dilakukan oleh tiga validator, dimana setiap validator berperan sebagai ahli media dan ahli materi. Hasil skor rata-rata prsentase diperoleh dari ahli media sebesar 95,13\% dengan kriteria kualitatif "dapat digunakan tanpa revisi", dan hasil skor ratarata presentase yang diperoleh dari ahli materi sebesar 95,23\% dengan kriteria kualitatif "dapat digunakan tanpa revisi" maka sesuai dengan uraian diatas dapat disimpulkan bahwa media ludo raksasa pada tema selalu berhemat energi, sangat valid digunakan untuk meningkatkan motivasi belajar siswa di kelas IV sekolah dasaar. 
Melihat dari ke-5 (lima) artikel para peneliti diatas dapat disimpulkan, hasil penulisan ini memberikan pernyataan yang nyata bahwa pembelajaran berbasis games education sangat mampu meningkatkan motivasi belajar siswa sekolah dasar, karena penerapan pembelajaran berbasis games education membantu memberikan semangat terhadap siswa untuk belajar karena anak-anak sangat senang ketika kegiatan belajar mengajar mereka disatukan dengan permainan.

Namun dari kelebihan yang dimiliki oleh pembelajaran berbasis games ini tidak luput dari yang namanya kekurangan, gamaes education yang terdapat dari artikel para penelitian yang telah diuraian diatas memiliki kekurangan masingmasing, untuk itu perlu adanya kemampuan guru dalam meminimalisir setiap kekurangan yang terdapat pada games education tersebut. Dalam proses pembelajaran, motivasi berperan sangat penting. Faturrohan, dkk. (2007: 20). Fungsi motivasi dalam belajar adalah mendorong seseorang untuk berbuat dan bertindak; motivasi menentukan arah perbuatan; motivasi menyeleksi perbuatan kita.

\section{KESIMPULAN}

Berdasarkan hasil kajian, maka penulis dapat menyimpulkan bahwa terdapat pengaruh pembelajaran berbasis games dalam peningkatan motivasi belajar siswa sekolah dasar, hal ini dapat dilihat dari hasil-hasil penelitian di atas, dimana pembelajaran berbasis games education lebih efektif dan efisien. Hal ini dapat dipahami bahwa dengan motivasi belajar seorang siswa akan terdorong untuk belajar. Hal ini disebabkan siswa diberikan kebebasan, siswa dapat terlibat langsung mengambil keputusan dan pembelajaran akan lebih menarik dan antusias siswa yang tinggi.

\section{UCAPAN TERIMA KASIH}

Ucapan terimakasih kepada Bapak Adi Apriadi Adiansha, M.Pd. sebagai dosen pengampuh matakuliah pembelajaran matematika SD yang memberikan tugas mata kuliah dalam penyusunan Jurnal.

\section{DAFTAR PUSTAKA}

Afandi, R. 2015. Pengembanga Media Pembelajaran Permainan Ular Tangga Untuk Meningkatkan Motivasi Belajar Siswa dan Hasil Belajar IPS di Sekolah Dasar. JINoP (Jurnal Inovasi Pembelajaran), 1(1), 77-89.

AM, I. A,. Saputra, S. Y., \& Amelia, D, J. (2018). Pembelajaran Tematik Integratif Pada Kurikulum 2013 di Kelas Rendah SD Muhammadiyah 07 Wajak. JINoP (Jurnal Inovasi Pembelajaran), 4(1), 35-46.

Anjani, K. D., Fatchan, A., \& Amirudin, A. (2016). Pengaruh pembelajaran berbasis turnamen dam games terhadap motivasi belajar siswa. Jurnal pendidikan: Teori, dan pengembangan, 1(9), 1787-1790.

Djamaluddin, M. (2019). Perancangan Aplikasi Games Education Matematika Berbasis Android Pada SDN 35 Sinjai. Jurnal IT, 10(1), 103-113.

Ismail, Andang, (2006), Education Games, Yogyakarta: Pilar Media.

Jihan, A. N. F., Reffiane, F., \& Arisyanto, P. (2019). Pengembangan Media Ludo Raksasa Pada Tema Selalu 
Mulyani, R. (2014). Analisis Kesalahan Siswa Dalam Menulis Kata Bahasa Inggris Pada Tema Part Of Body (Penelitian Deskriptif Kualitatif Pada Pembelajaaran Bahasa Inggris Kelas III SD Negeri Cipari Kecamatan Karangnunggal Kabupaten Tasikmalaya) (Doctoral dissertation, Universitas Pendidikan Indonesia).

Nasution, B. (2012). Meningkatkan Motivasi Belajar Siswa Dengan Menggunakan Metode Bermain Sambil Belajar (Permainan Monopoli) Pada Pokok Bahasan Penggolongan Hewan di Kelas IV SDN 101765 Bandar setia TA 2011/2012 (Doctoral dissertation, UNIMED).

Putri, A. E. (2019). Evaluasi Program Bimbingan dan Konseling: Sebuah Studi Pustaka. Jurnal bimbingan konseling indonesia 4(2), 39-42.

Putri, W. S. M. (2018). Model Pembelajaran Anak Berkebutuhan Khusus (ABK) Yang Berfokus Pada Siswa Lamban Belajar (Slow Leaner) (Studi penelitian din SLB Autism River Kids Kota Malang) (Doctoral dissertation, University of Muhammadiyah Malang).

Rasidi, M. A., \& Setiawati, F.A. (2015). Faktor-faktor kesulitan guru pada pembelajaran tematik integratif di SD Mataram. jurnal prima edukasi, 3(2), 155156.

Rifki dalam. Afandi, R. (2015). Pengembanga Media Pembelajaran Permainan Ular Tangga Untuk Meningkatkan Motivasi Belajar Siswa dan Hasil Belajar IPS di Sekolah Dasar. JINoP (Jurnal Inovasi Pembelajaran), 1(1), 77-89.

Rohmawati,E. D., \& Sukanti, S. (2012). Pengaruh Cara Belajar dan enggunaan Media Pembelajaran Terhadap Prestasi Belajar Akuntasi Siswa Kelas XI IPS SMA Negeri 2 Bantul Tahun Ajaran 2011/2012. Jurnal Pendidikan Akuntasi Indonesia, 10(2).

Sunarti, S., Rahmawati, S., \& Wardani, S. (2016). Pengembangan Game Petualangan "Si Bolang" Sebagai Media Pembelajaran Tematik Untuk Meningkatkan Motivasi dan Prestasi Belajar Siswa Kelas V Sekolah Dasar cakrawala pendidikan, (1). 84368.

Widiantari, N. M. A., Pudjawan, K., \& Japa, I. G. N. (2013). Penerapan Model Pembelajaran Teams Games Turnament (TGT) Untuk Meningkatkan Motivasi dan Ketrerampilan Berbicara Kelas IV SDN Tihingan. MIMBAR PGSD Undiksha, 1(1).

Wulandari, B., \& Surjono, H. D. (2013). Pegaruh problem-based learnig terhadap hasil belajar ditinjau dari motivasi belajar PLC di SMK. Jurnal pendidikan vokasi. 3(2).

Yulianci, S., Nurjumiati, N., Asriyadin, A., \& Adiansha, A. A. (2021). The Effect of Interactive Multimedia and Learning Styles on Students' Physics Creative Thinking Skills. Jurnal Penelitian Pendidikan IPA, 7(1), 87. https://doi.org/10.29303/jppipa.v7i1.529

Yusnitasari, N. (2017). The Influence Of Role Play Technique On The Students Speaking Ability At The Elevent Graders Of SMK $N 1$ Pekalongan East Lampung (doctoral dissertation, IAIN Metro).

Zulkifly. L, (2003), Psikologi Perkembangan, Bandung: Rosdakarya.

@ 2021 JagoMipa (https://bimaberilmu.com/jurnal/index.php/jagomipa) 